\title{
Proliferating Cell Count
}

National Cancer Institute

\section{Source}

National Cancer Institute. Proliferating Cell Count. NCI Thesaurus. Code C128794.

The number of proliferating cells found during a review of a slide(s) derived from a tissue sample. 